\title{
Opracowanie koncepcji uzyskiwania strumieni gazu o podwyższonej zawartości helu na membranach
}

\author{
Development of the concept of obtaining gas streams on membranes with increased \\ helium content
}

\author{
Andrzej Janocha \\ Instytut Nafty i Gazu - Państwowy Instytut Badawczy
}

\begin{abstract}
STRESZCZENIE: W związku z ciągłym wzrostem cen helu, wynikającym z kurczącej się w perspektywie lat podaży, rezerwy helu ze źródeł niszowych, w tym o niskiej jakości oraz z odzysku helu, w stosujących go branżach będą atrakcyjne. Konwencjonalne technologie produkcji helu są energochłonne i z założenia projektowane były dla dużych strumieni do obróbki (odzysku) helu z gazu ziemnego. Alternatywne technologie, np. z wykorzystaniem separacji membranowej, są coraz częściej badane ze względu na korzyści ekonomiczne, jakie mogą potencjalnie oferować w stosunku do konwencjonalnego podejścia. W niniejszym artykule dokonano przeglądu literaturowego w zakresie stosowanych technologii membranowej separacji helu z gazu ziemnego. Opracowano projekt i utworzono stanowisko badawcze do testów separacji na modułach membranowych mieszanin gazowych o różnej zawartości helu. Przeprowadzono kilka serii badań z interpretacją wyników eksperymentalnych zależności efektów wzbogacenia permeatu w hel od współczynnika podziału. Wykonano symulację i obliczenia wielkości strumieni w wielostopniowej instalacji separacji helu z gazu ziemnego w funkcji współczynników podziału z zawracaniem strumieni retentatu na wcześniejsze etapy rozdziału. Opracowano koncepcję uzyskiwania z gazu ziemnego zawierającego 0,3\% helu strumienia gazu o wysokiej, ponad 90-proc. zawartości helu z zastosowaniem technologii membranowej. Badania przeprowadzono na dostępnej komercyjnie membranie poliimidowej. W kolejnych stopniach wzbogacenia strumienia gazu w hel uzyskano 1,3\%,8\%, 37\% i ponad 93\% helu w końcowym koncentracie. W wysokociśnieniowym strumieniu retentatu otrzymano produkt niezawierający helu $(<0,02 \%)$ będący jednocześnie gazem o podwyższonej kaloryczności ze zmniejszoną zawartością dwutlenku węgla i azotu. W trakcie eksperymentów dążono do tego, aby wyniki były w szerokim zakresie przydatne w obliczeniach procesowych. Rozwiązany został symulacyjny ogólny problem kształtowania się przepływów (wielkości strumieni) dla układu czterostopniowego wzbogacania gazu na membranach. Wyniki obliczeń mogą służyć wielu wariantom w zależności od przepływu i od współczynników podziału $\Theta$. Określono wpływ dławienia ciśnienia permeatu na efekty separacyjne i ustalono optymalny zakres tego ciśnienia, biorąc pod uwagę konieczność sprężania tego strumienia. Przeprowadzone obliczenia inżynieryjne dla jednego z wariantów wykazały skuteczność i możliwość jego wdrożenia. Po każdym etapie (stopniu) separacji permeat musi być sprężony ponownie, co niesie za sobą określone nakłady eksploatacyjne związane z kosztami energii do sprężania i chłodzenia poszczególnych strumieni gazu. Obliczono wymaganą moc do sprężania i chłodzenia tych strumieni.
\end{abstract}

Słowa kluczowe: separacja membranowa, hel, gaz ziemny.

ABSTRACT: Due to the constantly rising helium prices, resulting from the shrinking supply, reserves of helium from niche sources, including those of low quality, will become attractive. Conventional helium production technologies are energy-consuming and were designed for large streams to process (recover) helium from natural gas. Alternative technologies, e.g. using membrane separation, are being more and more often explored because of the economic benefits they can potentially have over the conventional approach. This article reviews the literature on the technologies used for membrane separation of helium from natural gas. The project was developed and a test stand was created for separation tests on membrane modules of gas mixtures with different helium content. Several series of studies were carried out with interpretation of the results of experimental dependence of the effects of helium permeate enrichment on stage cut. Simulations and calculations of the size of streams were carried out in a multi-stage helium separation system from natural gas as a function of stage cuts with retentate streams being recycled to earlier stages of separation. The concept of obtaining natural gas containing $0.3 \%$ helium gas stream with high helium content - over $90 \%$ - using membrane technology was developed. The tests were carried out on a commercially available polyimide membrane. The subsequent stages of enrichment of the gas stream in helium, $1.3,8$, 37 and over $93 \%$ helium in the final concentrate were obtained. In the high-pressure retentate stream, a helium-free product $(<0.02 \%)$ was obtained which was also a gas with increased calorific value with a reduced content of carbon dioxide and nitrogen. During the

Autor do korespondencji: A. Janocha, e-mail: andrzej.janocha@inig.pl

Artykuł nadesłano do Redakcji: 05.08.2020 r. Zatwierdzono do druku: 28.09.2020 r. 
experiments, a lot of effort was put into making the results broadly useful in process calculations. The general simulation problem of flow shaping (stream sizes) for a four-stage gas enrichment system on membranes has been solved. The calculation results can serve many variants depending on the flow and on stage cut $\Theta$. The influence of permeate throttling pressure on separation effects was determined and the optimal range of this pressure was determined taking into account the need to compress this stream. The engineering calculations carried out for one of the variants showed the effectiveness and the possibility of its implementation. After each separation stage (degree), the permeate must be compressed again, which entails specific operating expenses related to the energy costs for compressing and cooling individual gas streams. The required power for compressing and cooling these streams was calculated.

Key words: membrane separation, helium, natural gas.

\section{Wprowadzenie}

Całkowita produkcja czystego helu odzyskanego z wydobywanego w Polsce gazu ziemnego wyniosła w 2017 roku 3172 tys. $\mathrm{m}^{3}$ (Szuflicki et al., 2018). W tej wielkości mieści się także około 800 tys. $\mathrm{m}^{3}$ helu pozyskiwanego $\mathrm{z}$ jednostopniowej instalacji membranowej w Kościanie, która dostarcza surowiec (0,8-proc. koncentrat helu) do instalacji kriogenicznej w Odolanowie (Chołast i Chmielecki, 2017). Najwięcej złóż gazu zawierających hel występuje na Niżu Polskim, ale można je także spotkać na przedgórzu karpackim. Hel jest produktem ubocznym radioaktywnego rozpadu ciężkich pierwiastków znajdujących się w skorupie ziemskiej, proces ten trwa setki milionów lat. Ceny helu są w przybliżeniu 60-80 razy wyższe od gazu ziemnego (w przeliczeniu na tę samą jednostkę objętościową). Analitycy przewidują, że popyt na hel będzie rósł rocznie do $9 \%$ w ciągu następnej dekady, znacznie powyżej podaży (Clarke et al., 2013; American Helium, 2018). W nadchodzących dziesięcioleciach globalna produkcja będzie poniżej globalnego popytu (Scholes, 2011; Hamak, 2019). Oczekuje się, że wzrost ceny helu sprawi, że jego rezerwy ze źródeł niskiej jakości oraz z odzysku helu w stosujących go branżach będą atrakcyjne (Scholes et al., 2017). Konwencjonalne technologie produkcji helu są energochłonne. Alternatywne technologie, np. z wykorzystaniem separacji membranowej, są coraz częściej badane ze względu na korzyści ekonomiczne, jakie mogą potencjalnie przynieść w stosunku do konwencjonalnego podejścia (Ruffordet al., 2014; Scholes et al., 2017). Oddzielenie helu od gazu ziemnego za pomocą membran komercyjnych zostało zaproponowane już ponad 50 lat temu (Stern et al., 1965). Od tamtego czasu prowadzono wiele prac badawczych i niewielkich instalacji pilotażowych, w tym także w Polsce (Janocha, 1989, 2014; Janocha et al., 2012; Szwast et al., 2014). Przeważająca część badań związanych z membranami skupia się na poprawie selektywności $\mathrm{He} / \mathrm{N}_{2}$ i He/ $\mathrm{CH}_{4} \mathrm{w}$ celu osiągnięcia jak najwyższego stopnia odzysku helu (Scholes i Ghosh, 2016; Dibrov et al., 2018). Drugim kierunkiem rozwijania technologii membranowej dla uzyskania wysokiego stopnia koncentracji helu jest jej połączenie z kolejnym stopniem $w$ dwóch lub trzech etapach recyklingu (Seok et al., 1986; Hale i Lokhandwala, 2005; Scholes i Ghosh, 2016; Wang et al., 2019) lub z inną technologią separacyjną (np.: PSA, TSA, Krio) (Doshi et al., 1989; Laguntsov et al., 2015; Alders et al., 2017; Atlaskin et al., 2019). Trzecim kierunkiem możliwości pozyskania helu jest opcja, w której wykorzystywany jest gaz do produkcji LNG. Niejako przy okazji skraplania gazu ziemnego nawet o małej koncentracji helu pozostaje on w produkcie ubocznym, a kluczowe parametry, które wpływają na zużycie energii w procesie, zostały przeanalizowane (Wojtowicz, 2013; Ma i Du, 2019). Jeśli chodzi o propozycje wdrożeniowe, to obok tradycyjnych firm oferujących instalacje membranowe do separacji helu z gazu ziemnego MTR, UOP, UBE ostatnio pojawiły się kolejne propozycje: Generon (2017), Grasys (2018), ALaS (Air Liquide, 2019) i Sepuran (2019) oraz opublikowano rezultaty z bardzo zaawansowanego programu rozwojowego SBIR-STTR (SBIR, 2019).

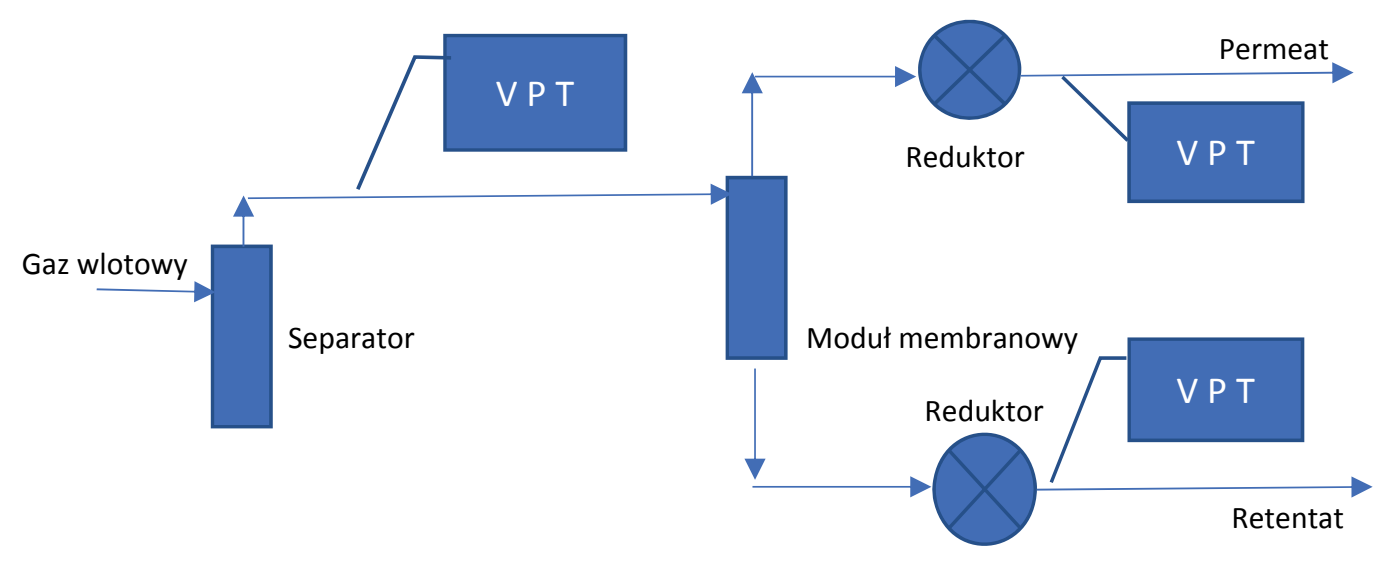

Rys. 1. Schemat instalacji do badania rozdziału mieszaniny gazu zawierającego hel na module membranowym. Oznaczenia: $\mathrm{PB}$ - miejsce poboru próbek, $\mathrm{V}$ - przepływomierze, $\mathrm{P}$ - manometry, T - termometry

Fig. 1. Installation diagram for testing the distribution of helium-containing gas mixture on the membrane module. Designations: $\mathrm{PB}$ - place of sampling, V - flow meters, $\mathrm{P}$ - manometers, $\mathrm{T}$ - thermometers 


\section{Instalacja badawcza}

Do badań separacji mieszanin gazowych zawierających hel wykorzystano moduł z membranami poliimidowymi, kierując się ich wysoką selektywnością i stabilnością separacyjną w długim czasie. Instalację doposażono w odpowiednie reduktory gazowe, zawory regulacyjne, mierniki ciśnienia i temperatury oraz wysokiej klasy przepływomierze, a jej schemat przedstawiono na rysunku 1.

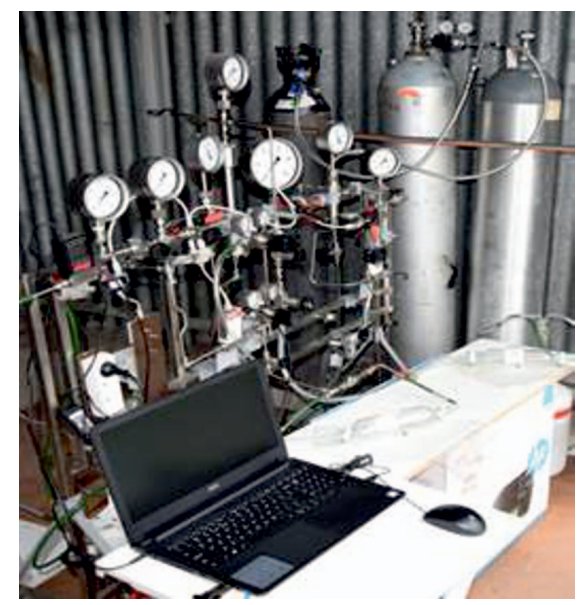

Rys. 2. Zdjęcie instalacji do badania rozdziału mieszaniny gazu zawierającego hel na module membranowym

Fig. 2. Installation for testing the separation of a helium gas mixture on a membrane module

Przygotowaną mieszankę gazową z butli kierowano do niewielkiego separatora, który jednocześnie pełnił rolę buforowania ciśnienia i następnie poprzez zawór iglicowy gaz wpływał przez układ pomiarowy do modułu. Uzyskane strumienie produktowe poprzez układy pomiarowe wpływały do pipet poboru próbek do analizy. Przepływomierze kalibrowane były każdorazowo przed poszczególnymi seriami testowymi z uwzględnieniem składów gazu. Wyniki pomiarowe po skalibrowaniu przesyłane były do komputera, gdzie poprzez odpowiednie oprogramowanie odczytywano wszystkie bieżące przepływy gazu (w nl/min).

\section{Badania}

Po wstępnej serii badań dla gazu zawierającego około $1 \%$ He uzyskano informacje o tendencjach kształtowania się składów gazu w strumieniach produktowych (permeatu i retentatu) w funkcji przepływu, ciśnienia i współczynnika podziału (współczynnik podziału definiuje się jako stosunek przepływu permeatu do przepływu gazu wlotowego).

Pierwszą zasadniczą serię testów przeprowadzono dla gazu zawierającego około $0,3 \%$ helu, reprezentującego gaz wsadowy do proponowanej koncepcji. Poprzez dodawanie do butli czystych składników sporządzono w INiG - PIB mieszaninę gazową, której oznaczony chromatograficznie skład przedstawiono w tabeli 1.

Tabela 1. Skład gazu wlotowego do pierwszej serii testów separacji helu

Table 1. The composition of the inlet gas for the first series of tests of separation of helium

\begin{tabular}{|c|c|}
\hline Składnik & {$[\%]$} \\
\hline \hline $\mathrm{CO}_{2}$ & 0,246 \\
\hline $\mathrm{He}$ & 0,289 \\
\hline $\mathrm{N}_{2}$ & 34,634 \\
\hline $\mathrm{CH}_{4}$ & 64,831 \\
\hline
\end{tabular}

Testy tej serii przeprowadzono przy ciśnieniu nadawy 65 bar, ciśnieniu permeatu 3,4 bar, temperaturze $25^{\circ} \mathrm{C}$ i przepływach odpowiadających współczynnikom podziału w zakresie $0,1-0,15$, co przedstawiono na rysunkach 3 i 4 .

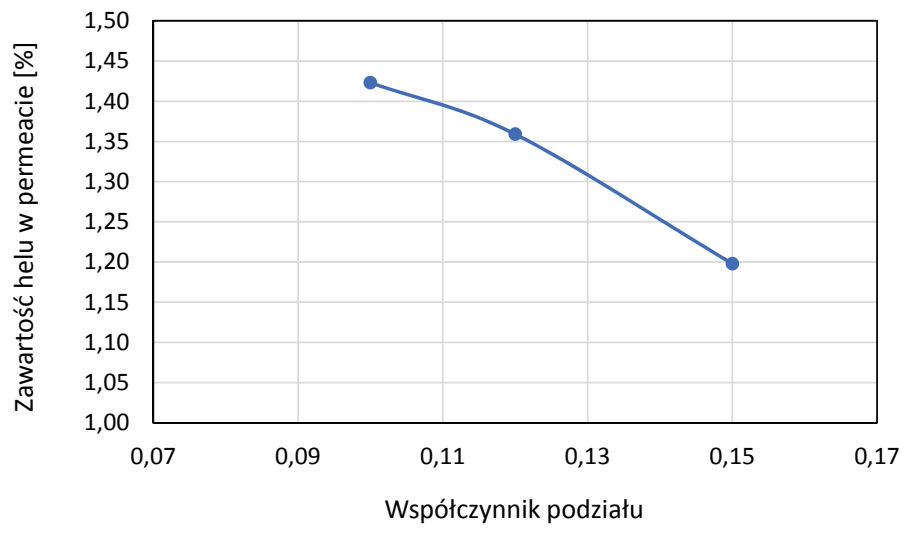

Rys. 3. Zależność zawartości helu w permeacie od współczynnika podziału

Fig. 3. Dependence of helium content in the permeate on stage cut

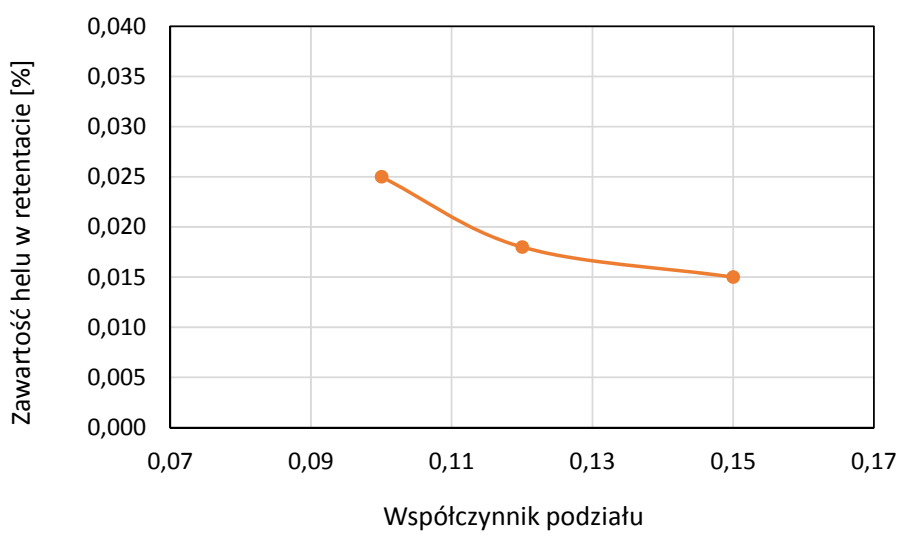

Rys. 4. Zależność zawartości helu w retentacie od współczynnika podziału

Fig. 4. Dependence of helium content in the retentate on stage cut

Jak wynika z przeprowadzonych testów, ich rezultaty wpisują się w zakresy wyników większości firm oferujących membrany komercyjne. Dla badanej membrany poliimidowej 
osiągnięto stężenia helu w retentacie (residual gas) poniżej $0,02 \%$ (rys. 4) przy współczynniku podziału $\Theta$ około 0,12 . Odpowiadające temu stężenie permeatu (rys. 3) wynosi około $1,36 \%$. W celu kontynuowania koncepcji wielostopniowej separacji helu na membranach skupiono się na wytworzeniu kolejnej mieszanki gazowej odpowiadającej temu stężeniu.

Drugą serię badań przeprowadzono dla gazu wlotowego do instalacji o składzie przedstawionym w tabeli 2 .

Tabela 2. Skład gazu wlotowego do drugiej serii testów separacji helu

Table 2. The composition of the inlet gas for the second series of tests of separation of helium

\begin{tabular}{|c|c|}
\hline Składnik & {$[\%]$} \\
\hline \hline $\mathrm{CO}_{2}$ & 0,9715 \\
\hline $\mathrm{He}$ & 1,3607 \\
\hline $\mathrm{N}_{2}$ & 47,8462 \\
\hline $\mathrm{CH}_{4}$ & 49,8215 \\
\hline
\end{tabular}

Istotne dla procesu w warunkach przemysłowych jest obok odpowiedniego efektu separacyjnego - uzyskanie permeatu o takim ciśnieniu, aby ograniczyć wymaganą moc do jego późniejszego doprężania. Pierwsze testy poświęcone więc były określeniu wpływu dławienia ciśnienia permeatu na efekty separacyjne. Badania te prowadzono przy ciśnieniu wlotowym 70 bar, współczynniku podziału od 0,116 do 0,119 dla różnych ciśnień permeatu, co przedstawiono na rysunku 5 .

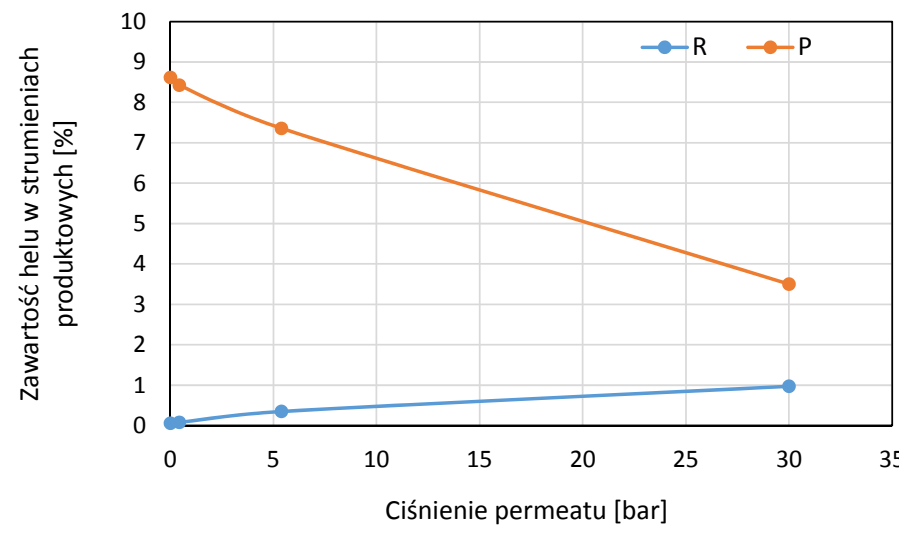

Rys. 5. Zależność zawartości helu w strumieniach produktowych ( R i P) od ciśnienia permeatu

Fig. 5. Dependence of helium content in product streams on permeate pressure

Jak wynika z rysunku 5, wzrost ciśnienia odbioru permeatu obniża efekty separacyjne, zwłaszcza przy dużych ciśnieniach dławienia. Należy więc wybrać maksymalne ciśnienie permeatu, dla którego zgodnie z założoną koncepcją zawracania retentatu do poprzedniego stopnia separacji zawartość helu w gazie nie przekroczy $0,3 \%$. Na rysunku 6 przedstawiono wycinek rysunku 5 wyznaczający maksymalne ciśnienie permeatu.

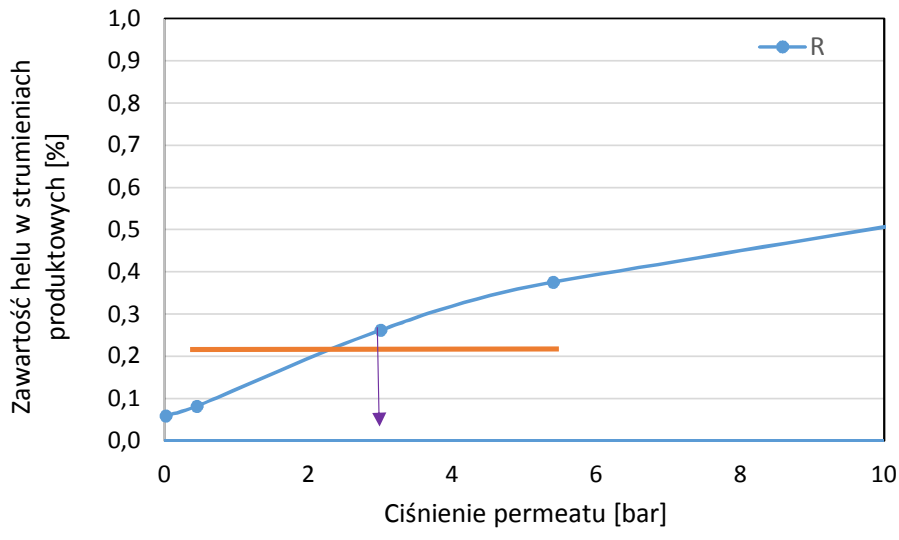

Rys. 6. Zależność zawartości helu w strumieniu retentatu od ciśnienia permeatu z wyznaczeniem maksymalnego ciśnienia permeatu

Fig. 6. Dependence of helium content in the retentate stream on the permeate pressure, with the determination of the maximum permeate pressure

Jak wynika z rysunku 6 , dla tego zakresu badań dławienie permeatu nie powinno przekraczać 3,4 bar. Takie ciśnienie permeatu, choć obniża efekt separacyjny, mieści się dobrze w zakresie minimalnego dopuszczalnego ciśnienia ssania sprężarek, których wykorzystanie jest planowane w całościowej koncepcji procesowej. Kształtowanie się zawartości helu w strumieniach produktowych w procesie separacji membranowej przy ciśnieniu wlotowym 66 bar i ciśnieniu permeatu 3,3 bar przedstawiono na rysunku 7 .

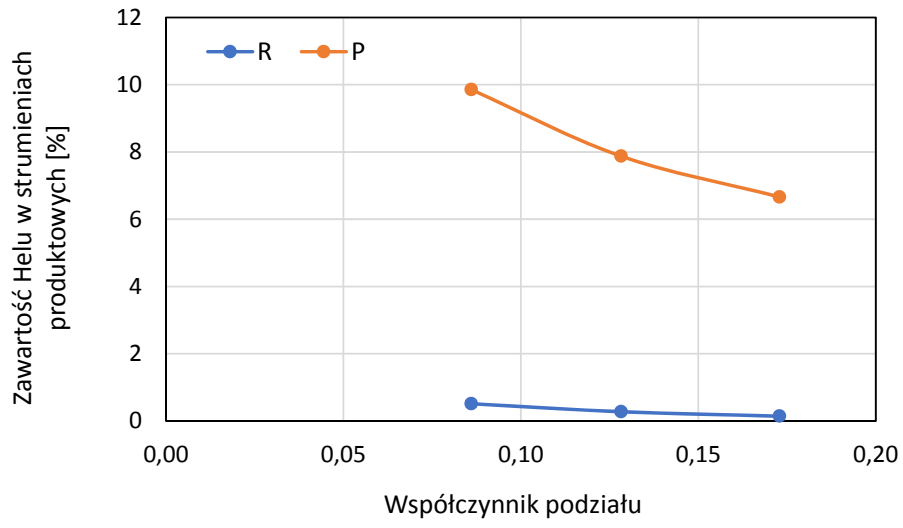

Rys. 7. Zależność zawartości helu w strumieniach produktowych od współczynnika podziału

Fig. 7. Dependence of helium content in product streams on stage cut

Zawartość helu w retentacie odpowiadająca zawartości w gazie wlotowym pierwszej serii badań $(0,3 \%)$ uzyskiwana jest przy współczynniku podziału na poziomie około 0,13 . Zawartość helu w permeacie w ww. zakresie odpowiada $8,3-8,4 \%$ helu w gazie. Te wartości zostały użyte do symulacji wielostopniowej procesu separacji membranowej oraz do wytworzenia kolejnej mieszanki do badań w następnym teście. Trzecią serię badań przeprowadzono dla gazu wlotowego do 
instalacji zawierającego około 8,36\% helu. Testy w tej sekwencji badań wykonano dla ciśnienia wlotowego 68 bar i ciśnienia permeatu 3,4 bar. Przy tak dużej zawartości helu w gazie wlotowym (ponad 8,3\%) bardzo wyraźnie wzrosły przepływy permeatu w stosunku do wcześniejszych testów. Zależności zawartości helu w strumieniach produktowych od współczynnika podziału przedstawiono na rysunku 8 .

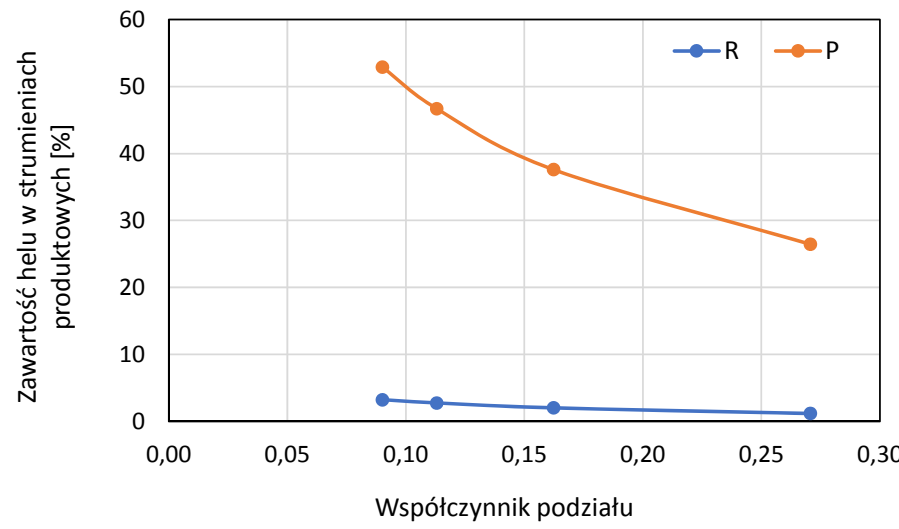

Rys. 8. Zależność zawartości helu w strumieniach produktowych od współczynnika podziału

Fig. 8. Dependence of helium content in product streams on stage cut

Zawartość helu w retentacie odpowiadająca zawartości w gazie wlotowym drugiej serii badań (1,36\%) uzyskiwana jest przy współczynniku podziału na poziomie około 0,22. Zawartość helu w permeacie w wyżej wymienionym zakresie odpowiada około $37 \%$ helu w gazie. Te wartości zostały użyte do symulacji wielostopniowej procesu separacji membranowej oraz do wytworzenia kolejnej mieszanki do badań w następnym teście. Czwartą serię badań przeprowadzono dla gazu wlotowego do instalacji zawierającego 37,4\% helu. Testy w tej sekwencji badań wykonano dla ciśnienia wlotowego 69 bar i ciśnienia permeatu 3,3 bar. Po skalibrowaniu przepływomierzy na podstawie analizy chromatograficznej strumieni produktowych przy ciśnieniu wlotowym 69 bar wykonano dla tego ciśnienia pojedynczy pomiar składu permeatu i retentatu przy ciśnieniu permeatu, które osiągnęło 0,07 bar, na tzw. wolny wypływ (opory przepływu przez pipety do poboru próbek). Zawartość helu w permeacie wynosiła ponad 96\%. Nie udało się uzyskać stabilnego przepływu strumieni dla współczynnika podziału $(\Theta)$ poniżej 0,25 i ciśnienia permeatu na poziomie około 3,4 bar ze względu na bardzo wysokie przepływy obu strumieni i zakres pomiarowy przepływomierzy. Zawartość helu w permeacie wahała się wówczas wokół stężenia 93\%. Bardzo wysokie przepływy w trakcie tych operacji spowodowały szybki spadek ciśnienia w butli w gazie wsadowym, co spowodowało konieczność prowadzenia dalszych testów przy współczynnikach podziału wyższych od 0,25 . W zakresie $\Theta$ od 0,27 do $0,33 \mathrm{w}$ permeacie uzyskiwano wysokie stężenia helu (ponad 90\%), a w retentacie 7-10\%. Wyniki testów separacji przy współczynnikach podziału powyżej 0,25 przedstawiono na rysunku 9.

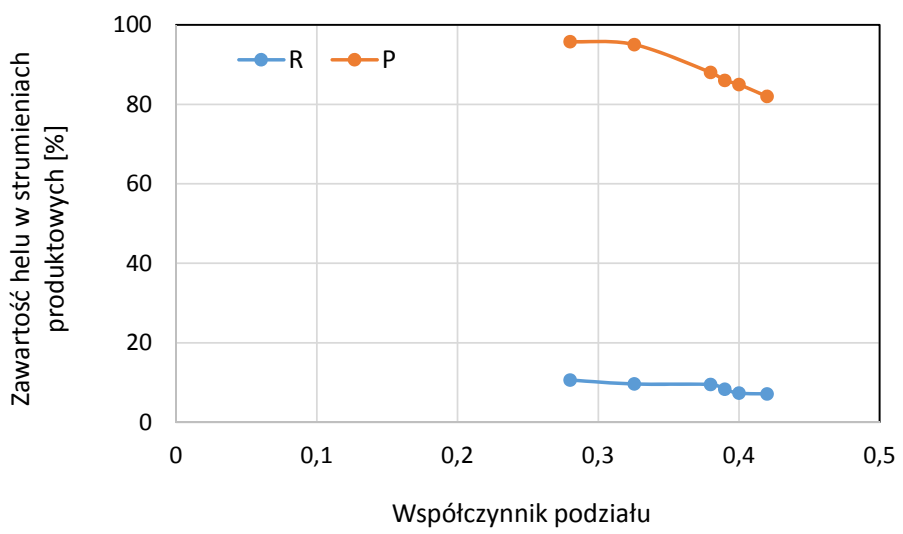

Rys. 9. Zależność zawartości helu w strumieniach produktowych od współczynnika podziału (gaz wlotowy około 37\% He)

Fig. 9. Dependence of helium content in product streams on stage cut (inlet gas approx. 37\% $\mathrm{He}$ )

Zawartość helu w retentacie odpowiadającą zawartości w gazie wlotowym trzeciej serii badań $(8,36 \%)$ można uzyskać, regulując ciśnienie permeatu przy współczynniku podziału na poziomie około 0,25 , co zostało użyte w symulacji wielostopniowej.

\section{Symulacja wielostopniowej separacji helu z gazu ziemnego}

Prowadzone testy na instalacji w skali laboratoryjnej na module z poliimidową membraną, odzwierciedlającą warunki przemysłowe, pozwalają na symulację procesu wielostopniowej separacji helu z gazu ziemnego w celu uzyskania jego wysoko skoncentrowanego produktu. Testy wykonywane były na nieprzypadkowych stężeniach helu w gazie - wynikały z sekwencji kolejno uzyskiwanych wyników koncentracji helu w poszczególnych badaniach. Zawartość helu w gazie wlotowym w poszczególnych seriach testowych wynikała z zawartości helu w permeacie, a z drugiej strony z jego ilości w wysokociśnieniowym retentacie, który był zawracany do wcześniejszego stopnia separacyjnego odpowiadającego jego stężeniu na wlocie do danego stopnia rozdziału.

Istotą tej symulacji jest obliczenie poziomu przepływu poszczególnych strumieni w zależności od wartości współczynników podziału na poszczególnych stopniach separacji. Na rysunku 10 przedstawiono schemat ideowy czterostopniowej separacji mieszaniny gazu na membranach z zaznaczonymi przepływami gazu. W symulacji przyjęto zasadę, że zawartości helu w strumieniach zawracanych są takie same jak zawartości helu w strumieniach, do których są dołączane. 


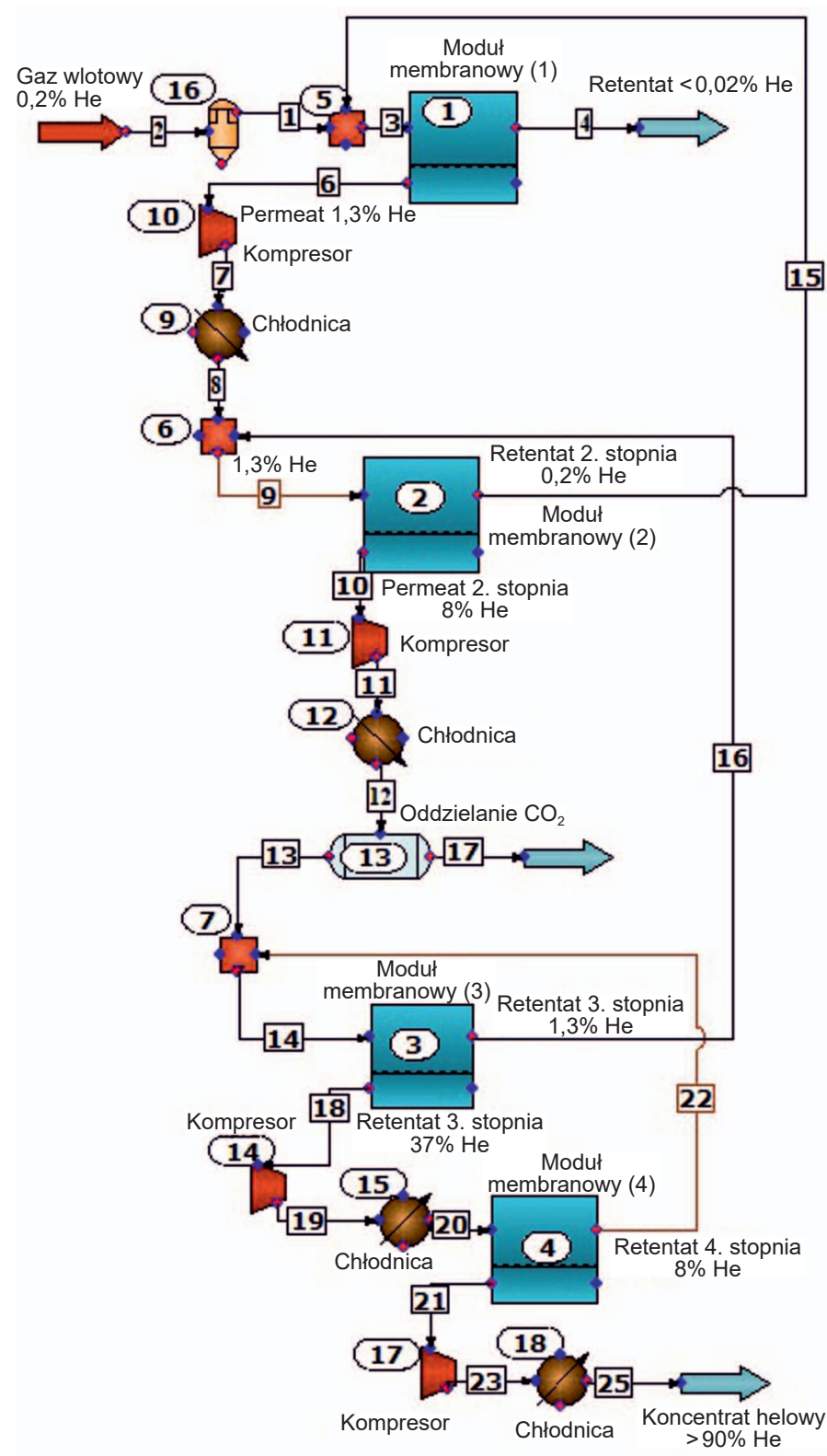

Rys. 10. Schemat ideowy czterostopniowej instalacji membranowej z zawracaniem strumieni. Oznaczenia: A do L - przepływy strumieni wlotowych i produktowych z poszczególnych modułów membranowych. $\Theta 1-\Theta 4$ - współczynniki podziału

Fig. 10. Schematic diagram of a four-stage membrane installation with recycled streams. Designations: A to $\mathrm{L}-$ inlet and products flow from individual membrane modules. $\Theta 1-\Theta 4$ - stage cut

Na podstawie badań eksperymentalnych znane są współczynniki podziału $\Theta$, odpowiadające uzyskaniu w strumieniach zawracanych koncentracji helu w gazie takich samych jak w strumieniu, do którego są zawracane. Dla rozważanego układu czterostopniowego znane są właśnie tylko te cztery wartości $(\Theta 1-\Theta 4)$, które muszą wystarczyć do obliczenia wszystkich strumieni zaznaczonych na rysunku 10. Na końcu obliczeń zakłada się również jakąś wartość umowną dla przepływu strumienia wlotowego A (np. $100 \mathrm{~m}^{3} / \mathrm{h}$ albo jakąkolwiek wartość odpowiadającą konkretnym warunkom rzeczywistym). Aby obliczyć poszczególne wartości przepływów zaznaczonych na rysunku 10, zestawiono poniżej układ równań wynikających ze schematu.

$$
\begin{aligned}
& \mathrm{A}+\mathrm{C}=\mathrm{B} \\
& \mathrm{B}=\mathrm{E}+\mathrm{D} \\
& \mathrm{E}+\mathrm{G}=\mathrm{F} \\
& \mathrm{F}=\mathrm{H}+\mathrm{C} \\
& \mathrm{H}+\mathrm{J}=\mathrm{I} \\
& \mathrm{I}=\mathrm{K}+\mathrm{G} \\
& \mathrm{K}=\mathrm{L}+\mathrm{J} \\
& \mathrm{E}=\mathrm{B} \cdot \Theta 1 \\
& \mathrm{H}=\mathrm{F} \cdot \Theta 2 \\
& \mathrm{~K}=\mathrm{I} \cdot \Theta 3 \\
& \mathrm{~L}=\mathrm{K} \cdot \Theta 4
\end{aligned}
$$

Ponadto z równań (1)-(7) (dodanie stronami) oraz z ich przekształceń wynikają równania pomocnicze:

$$
\begin{aligned}
& \mathrm{A}=\mathrm{D}+\mathrm{L} \\
& \mathrm{D}=\mathrm{B} \cdot(1-\Theta 1) \\
& \mathrm{C}=\mathrm{F} \cdot(1-\Theta 2) \\
& \mathrm{G}=\mathrm{I} \cdot(1-\Theta 3) \\
& \mathrm{J}=\mathrm{K} \cdot(1-\Theta 4)
\end{aligned}
$$

Na pierwszy stopień separacji wpływa strumień A uzupełniony o strumień $\mathrm{C}$, tworząc strumień $\mathrm{B}$. Kluczowymi wartościami pozwalającymi precyzyjnie obliczyć dalsze poszczególne strumienie są więc wartości B i C. W związku z tym, że wartość strumienia $\mathrm{C}$ zależy od strumienia $\mathrm{F}$ i kolejno $\mathrm{H}, \mathrm{J}$ i I - obliczenia rozpoczęto od znalezienia zależności pomiędzy tymi strumieniami w powiązaniu z odpowiadającymi im wartościami współczynników podziału. Wykorzystując równania (5), (10), (16), dochodzimy do równania:

$$
\mathrm{H}=\mathrm{I} \cdot(1-\Theta 3(1-\Theta 4))
$$

Kolejno, wykorzystując równania (3), (9), (10) i (15), uzyskujemy:

$$
E=F(1-\Theta 2 \cdot(1-\Theta 3)) /(1-\Theta 3 \cdot(1-\Theta 4))
$$

Jeśli wartość w nawiasie oznaczymy jako X:

$$
X=1-\Theta 2 \cdot(1-\Theta 3) /(1-\Theta 3 \cdot(1-\Theta 4))
$$

to:

$$
\mathrm{E}=\mathrm{F} \cdot \mathrm{X}
$$

Wykorzystując równania (8) i (14), otrzymujemy:

$$
\mathrm{C}=\mathrm{B} \cdot \Theta 1(1-\Theta 2) / \mathrm{X}
$$

A następnie z równań (1) i (21), uzyskujemy:

$$
\mathrm{B}=\mathrm{A}+\mathrm{B} \cdot \Theta 1(1-\Theta 2) / \mathrm{X}
$$

i ostatecznie po przekształceniu:

$$
\mathrm{B}=\mathrm{A} \cdot \mathrm{X} /(\mathrm{X}-\Theta 1(1-\Theta 2))
$$


Obliczenia kolejnych wartości strumieni w funkcji A, $\Theta 1$, $\Theta 2, \Theta 3$ i $\Theta 4$ są trywialne, wynikające bezpośrednio z równań (1)-(16). Obliczenia wartości strumieni wynikających z badań eksperymentalnych dokonano dla umownej jednostki przepływu równej 100 oraz dla $\Theta 1=0,12, \Theta 2=0,13, \Theta 3=0,22, \Theta 4$ $=0,25$, które to wartości współczynników podziału odpowiadają poszczególnym stopniom separacji wynikającym z badań eksperymentalnych.

Tabela 3. Wielkości przepływów strumieni

Table 3. Stream flow rates

\begin{tabular}{|r|l|}
\hline \hline $\mathrm{A}=$ & 100,000 \\
\hline $\mathrm{B}=$ & 113,486 \\
\hline $\mathrm{C}=$ & 13,486 \\
\hline $\mathrm{D}=$ & 99,867 \\
\hline $\mathrm{E}=$ & 13,618 \\
\hline $\mathrm{F}=$ & 15,501 \\
\hline $\mathrm{G}=$ & 1,882 \\
\hline $\mathrm{H}=$ & 2,015 \\
\hline $\mathrm{I}=$ & 2,413 \\
\hline $\mathrm{J}=$ & 0,398 \\
\hline $\mathrm{K}=$ & 0,531 \\
\hline $\mathrm{L}=$ & 0,133 \\
\hline $\mathrm{S}=$ & 16,164 \\
\hline
\end{tabular}

$\mathrm{S}(=\mathrm{E}+\mathrm{H}+\mathrm{K})$ jest sumą strumieni, które należy sprężyć.

Z symulacji tej wynika, że strumień produktowy D, będący retentatem pierwszego stopnia separacji, jest wysoki (nieznacznie mniejszy od strumienia wsadowego A), co związane jest bilansowo z drugim końcowym strumieniem produktowym całego układu czterostopniowego wzbogacania gazu - L, będącym koncentratem helu.

Schemat technologiczny instalacji przedstawiono na rysunku 11.

Osuszony gaz wlotowy poprzez filtr 16 i uzupełniony strumieniem 15 wpływa pod ciśnieniem około 64 bar do pierwszego stopnia separacji (zespołu modułów membranowych 1). Gaz ten, zawierający około 0,2\% helu, rozdziela się na dwa strumienie: retentat (zawierający poniżej $0,02 \% \mathrm{He}$ ), który odprowadzany jest do sieci gazowniczej, oraz permeat (około 1,3\% He), jako niskociśnieniowy produkt separacji, który sprężany jest w kompresorze 10 . Po schłodzeniu (chłodnica 9) i połączeniu ze strumieniem 16 wpływa do drugiego stopnia separacji (moduł membranowy 2) i rozdzielany jest na dwa strumienie: wysokociśnieniowy retentat (15), zawierający $0,2 \% \mathrm{He}$, który zawracany jest do modułu membranowego 1, oraz niskociśnieniowy permeat (10), zawierający około 8\% helu. Gaz ten zawiera (kumulujący się w permeacie) dwutlenek węgla (3-5\%), który po sprężeniu w kompresorze 11 i chłodzeniu kierowany jest do aparatu oddzielającego $\mathrm{CO}_{2}(13)$. Pozostały gaz po połączeniu ze strumieniem 22 (8\% He) wpływa na moduł membranowy 3 , a uzyskane w trzecim stopniu separacji strumienie zawierają odpowiednio: w retentacie $1,3 \%$ helu, w permeacie $37 \%$ helu. Retentat jest zawracany (do permeatu po pierwszym stopniu separacji), a permeat kierowany jest po sprężeniu i schłodzeniu na ostatni, czwarty stopień separacji. Retentat, zawierający około $8 \%$ helu, zawracany jest na wlot do modułu membranowego (3), a permeat jest końcowym produktem, zawierającym koncentrat helowy o zawartości ponad 90\% He i ciśnieniu 3,4 bar, który będzie sprężany do odpowiedniego ciśnienia w zależności od przeznaczenia. Strumienie z poszczególnych permeatów międzystopniowych sprężane będą do ciśnienia przewyższającego ciśnienie na wlot do poszczególnych modułów, z uwzględnieniem dodatkowo oporów przepływu przez moduł (lub zespół modułów). W zależności od wielkości przepływów należy przyjąć, że na kolejne moduły wpływać będzie gaz sprężony o około 2 bar powyżej ciśnienia w poprzednim stopniu separacji. Obecność dwutlenku węgla w składzie gazu na wlocie jest niekorzystna dla założonego celu, gdyż jest on drugim po helu najszybciej przenikającym przez tę membranę gazem, konkurującym w permeacji helu. W koncepcji założono, że jeśli ten gaz nie będzie oddzielony przed wlotem na instalację, to powinien być usunięty przed zasadniczymi krokami zagęszczania zawartości helu, najpóźniej po drugim stopniu separacji membranowej. Do obliczeń mocy sprężania strumieni 6, 10 i 18 przyjęto składy gazu z poszczególnych stopni separacji oraz wyliczone z rysunku 10 przepływy w tabeli 3 kolejno

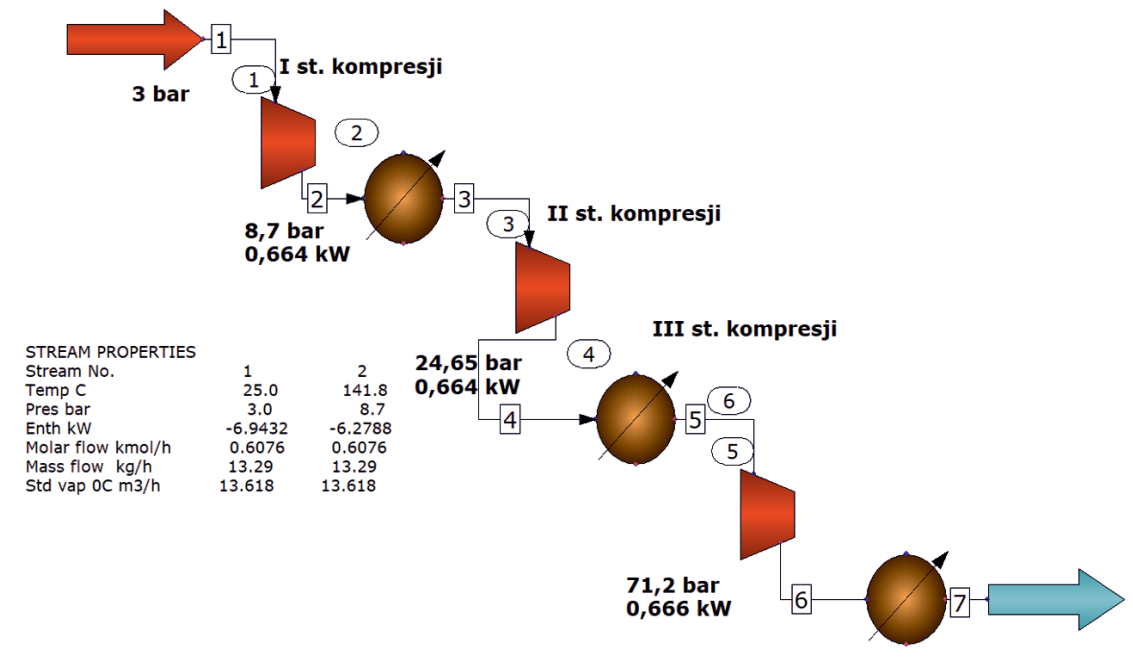

Rys. 11. Schemat technologiczny czterostopniowego procesu membranowej separacji helu z gazu ziemnego

Fig. 11. Technological diagram of the four-stage process of membrane separation of helium from natural gas 
dla strumieni $\mathrm{E}, \mathrm{H}$ i $\mathrm{K}$ : $\mathrm{E}=13,618, \mathrm{H}=2,015, \mathrm{~K}=0,531 . \mathrm{Na}$ rysunku 12 przedstawiono schemat trzystopniowej sprężarki z wybranymi danymi i wynikami obliczeń, które przeprowadzono w programie ChemCAD.

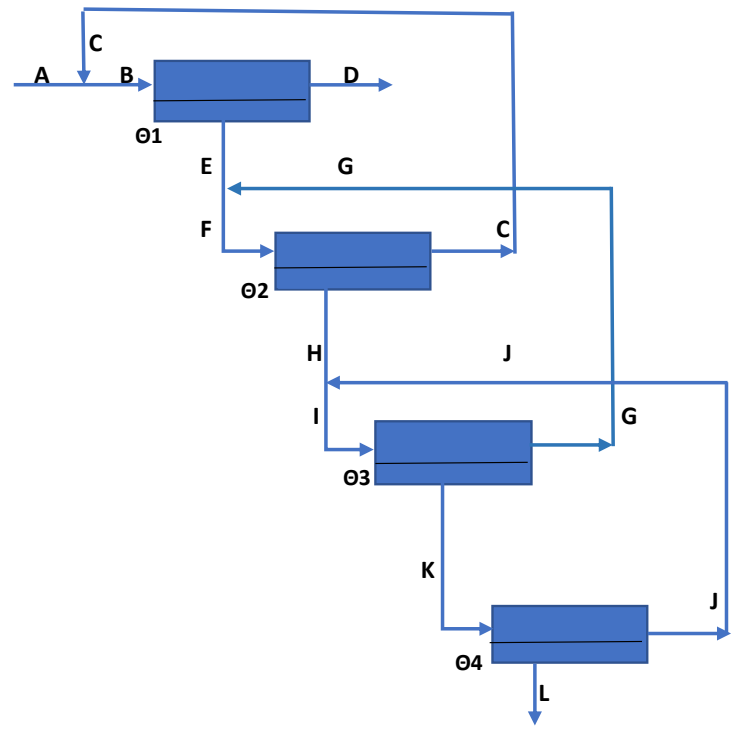

Rys. 12. Schemat do obliczeń trzystopniowej sprężarki permeatu po pierwszym stopniu separacji

Fig. 12. Diagram of calculation of a three-stage compressor of the permeate after the first separation stage

Razem moc sprężarki pierwszego stopnia wynosi około $2 \mathrm{~kW}$. Analogicznie obliczono wymagania mocy sprężania i chłodzenia dla kolejnych strumieni permeatów. Koncentrat helowy może być wykorzystywany rynkowo w różny sposób i jego wymagane zdawcze ciśnienie będzie zależeć od sposobu jego zagospodarowania. Sumując wymaganą moc do sprężania i chłodzenia międzyetapowego strumieni, można oszacować zapotrzebowanie mocy całej instalacji na poziomie 3,5-4 kW, co jest zgodne z poziomem mocy zużywanej dla podobnej wydajności $\left(16 \mathrm{~m}^{3} / \mathrm{h}\right) \mathrm{np}$. przez kompresory $\mathrm{CNG}$ (Oferta kompresorów CNG).

\section{Podsumowanie}

1. Zaprojektowano i dostosowano do pracy instalację ciśnieniową z odpowiednio dobraną armaturą i urządzeniami pomiarowymi zapewniającą stabilność przepływu w trakcie pomiarów.

2. Przeprowadzono serię testów pięciu mieszanek He w gazie ziemnym przy różnych przepływach i ciśnieniach poszczególnych strumieni.

3. Określono wpływ dławienia ciśnienia permeatu na efekty separacyjne i ustalono optymalny zakres tego ciśnienia, biorąc pod uwagę konieczność sprężania tego strumienia.
4. Rozwiązano symulacyjny ogólny problem kształtowania się przepływów (wielkości strumieni) dla układu czterostopniowego wzbogacania gazu na membranach, który może służyć wielu wariantom w funkcji przepływu i współczynników podziału $\Theta$.

5. Po każdym etapie (stopniu) separacji permeat musi być sprężony ponownie, co niesie za sobą określone nakłady eksploatacyjne związane z kosztami energii do sprężania i chłodzenia poszczególnych strumieni gazu. Obliczono wymaganą moc do sprężania tych strumieni.

6. Stwierdzono, że zastosowanie wielostopniowego zagęszczania helu na membranie poliimidowej pozwala na uzyskanie strumienia gazu z ponad 90-proc. jego zawartością. Badania te prowadzono przy ciśnieniach wlotowych uwzględniających warunki rzeczywiste (przemysłowe).

7. W wysokociśnieniowym strumieniu retentatu otrzymano produkt pozbawiony helu $(<0,02 \%)$, będący jednocześnie gazem o podwyższonej kaloryczności ze zmniejszoną zawartością dwutlenku węgla i azotu.

8. Opracowano schemat technologiczny czterostopniowego procesu membranowej separacji helu z gazu ziemnego.

9. Na podstawie badań opisano zachodzące zjawiska oraz określono możliwości wykorzystania rozdziału na membranach gazu zawierającego He w procesach jego uzdatniania.

Artykuł powstał na podstawie pracy badawczej pt. Opracowanie koncepcji uzyskiwania strumieni o podwyższonej zawartości helu na membranach - praca INiG - PIB na zlecenie MNiSW; nr zlecenia: 0035/KE/2019, nr archiwalny: KE-4101-25/2019.

\section{Literatura}

Air Liquide, 2019. <https://www.airliquideadvancedseparations.com/ helium-recovery-applications> (dostęp: wrzesień 2019).

Alders M., Winterhalder D., Wessling M., 2017. Helium recovery using membrane processes. Separation and Purification Technology, 189: 433-440. DOI: 10.1016/j.seppur.2017.07.084.

American Helium, 2018. Corporate Presentation, Q2 2018. <https:// amerihelium.com/wp-content/uploads/2018/05/American-HeliumCorporate-Presentation.pdf> (dostęp: wrzesien 2019).

Atlaskin A.A., Trubyanov M.M., Yanbikov N.R., 2019. Comprehensive experimental study of membrane cascades type of ,continuous membrane column” for gases high-purification. Journal of Membrane Science, 572: 92101. DOI: 10.1016/j. memsci.2018.10.079.

Chołast K., Chmielecki B., 2017. Membranowy odzysk helu z gazu ziemnego. Wiadomości Naftowe i Gazownicze, 8(226): 9-14.

Clarke R., Nuttall W., Glowacki B., 2013. Endangered helium: Bursting the myth. Chem. Eng., 870: 32-36.

Dibrov G., Ivanov M., Semyashkin M., Sudin V., Kagramanov G., 2018. High-Pressure Aging of Asymmetric Torlon ${ }^{\circledR}$ Hollow Fibers for Helium Separation from Natural Gas. Fibers, 6(4): 83. DOI: 10.3390/fib6040083.

Doshi K.J., Werner R.G., Mitariten M.J., 1989. Integrated Membrane/ PSA Process and System. U.S. Patent 4,863, 492.

Generon, 2017. <https://www.generon.com/wp-content/uploads/2017/03/HELIUM-RECOVERY.pdf> (dostęp: wrzesień 2019). 
Grasys, 2018. <http://www.grasys.com/company/news/3201/> (dostęp: wrzesień 2019).

Hale P., Lokhandwala K., 2005. Helium recovery from gas streams. US Patent App. 10/817,085.

Hamak J.E., 2019. Helium Mineral Commodity Summaries. U.S. Geological Survey: Reston, VA, USA. <https://prd-wret.s3-uswest-2.amazonaws.com/assets/palladium/production/s3fs-public/ atoms/files/mcs-2019-heliu.pdf> (dostęp: wrzesień 2019).

Janocha A., 1989. Rozdział metanu i azotu na membranach polimerowych. Nafta-Gaz, 4-5: 66-70.

Janocha A., 2014. Doradztwo procesowe w realizacji projektu wzbogacania w hel gazu ziemnego z wykorzystaniem modułów membranowych. Praca na zlec. PGNiG S.A. Archiwum Instytutu Nafty i Gazu-Państwowego Instytutu Badawczego, Kraków.

Janocha A., Piątkiewicz W., Szwast M., Bojarska M., Gliński A., Koźbiał J., 2012. Możliwości wzbogacania gazu ziemnego na membranach. Prace INiG, 118: 899-904.

Laguntsov N., Kurchatov I.M., Karaseva M.D., 2015. Membrane Recycle System Usage for Helium Extraction from Natural Gas. Physics Procedia, 72: 93-97. DOI: 10.1016/j.phpro.2015.09.026.

Ma G.-G., Du S., 2019. Analysis on the combination process of natural gas helium extraction and LNG production. Huaxue Gongcheng/Chemical Engineering. DOI: 10.3969/j. issn.1005-9954.2019.01.016.

Oferta kompresorów CNG. <https://www.galileoar.com/en/cng-compressors-and-dispensers-2/microbox-cngcompressor/> (dostęp: wrzesień 2019).

Rufford T.E., Chan K.I., Huang S.H., May E.F., 2014. A Review of Conventional and Emerging Process Technologies for the Recovery of Helium from Natural Gas. Adsorption Science \& Technology, 32: 49-72. DOI: 10.1260/0263-6174.32.1.49.

SBIR, 2019. <https://www.sbir.gov/sbirsearch/detail/687759> (dostęp: wrzesień 2019).

Scholes C.A., 2011. Helium: Is the party really over? Chem. Aust., 78: 18-20. ISSN: 0314-4240.

Scholes C.A., Ghosh U.K., 2016. Helium separation through polymeric membranes: Selectivity targets. J. Membr. Sci., 520: 221-230.
DOI: 10.1016/j.memsci.2016.07.064.

Scholes C.A., Ghosh U.K., Ho M.T., 2017. The Economics of Helium Separation and Purification by Gas Separation Membranes. Ind. Eng. Chem. Res., 56(17): 5014-5020. DOI: 10.1021/acs.iecr.7b00976.

Seok D.R., Kang S.G., Hwang S.T., 1986. Separation of helium and hydrocarbon mixtures by a two-membrane column. Journal of Membrane Science, 27(1): 1-11. DOI: 10.1016/ S03767388(00)81378-2.

Sepuran, 2019. <https:/www.sepuran.com/product/sepuran/en/helium/> (dostęp: wrzesień 2019).

Stern S.A., Sinclair T.F., Gareis P.J., Vahldieck N.P., Mohr P.H., 1965. Helium Recovery by Permeation. Ind. Eng. Chem., 57(2): 49-60.

Szuflicki M., Malon A., Tymiński M. (red.), 2018. Bilans zasobów złóż kopalin w Polsce wg stanu na 31 XII 2017 r. Państwowy Instytut Geologiczny - Państwowy Instytut Badawczy, Warszawa. ISBN (CD) 978-83-7863-979-4.

Szwast M., Zalewski M., Nikpour R., Sobczak A., 2014. Pozyskiwanie helu z gazu ziemnego za pomocą technik membranowych. Inż. Ap. Chem., 53(4): 304-305.

Wang X., Shan M., Liu X., Meng Wang M., Doherty C.M., Osadchii D., Kapteijn F., 2019. High-Performance Polybenzimidazole Membranes for Helium Extraction from Natural Gas. ACS Applied Materials \& Interfaces, 11(22): 20098-20103. DOI: 10.1021/acsami.9b05548.

Wojtowicz R., 2013. Ocena gazu granicznego G21 pod kątem jego przydatności do określenia jakości spalania gazów ziemnych wysokometanowych pochodzących z regazyfikacji LNG w urządzeniach użytku domowego. Nafta-Gaz, 8: 599-612.

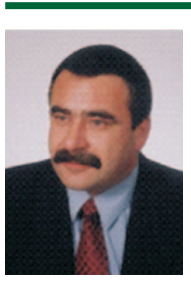

Dr Andrzej JANOCHA

Adiunkt w Zakładzie Technologii Eksploatacji

Płynów Złożowych

Instytut Nafty i Gazu - Państwowy Instytut Badawczy

ul. Lubicz $25 \mathrm{~A}$

31-503 Kraków

E-mail: andrzej.janocha@inig.pl

\section{OFERTA BADAWCZA ZAKŁADU TECHNOLOGII EKSPLOATACJI PŁYNÓW ZŁOŻOWYCH}

- optymalizacja procesów wydobycia i przygotowania do transportu ropy i gazu;

- bioremediacja gruntów, odpadów wiertniczych i eksploatacyjnych zanieczyszczonych substancjami ropopochodnymi;

- rekultywacja terenów skażonych substancjami ropopochodnymi;

- opracowywanie technologii oczyszczania ścieków eksploatacyjnych i wód złożowych z zanieczyszczeń ropopochodnych;

- badania i dobór inhibitorów parafinowo-hydratowych oraz deemulgatorów stosowanych w procesach eksploatacii ztóż węglowodorów;

- monitorowanie zmian zawartości związków siarki w podziemnych magazynach gazu i opracowanie koncepcji dziatań zapobiegaiących powstawaniu siarkowodoru w złożu;

- badania składu chemicznego płynów ztożowych;

- wykonywanie kart katalogowych oraz opracowanie opinii bezpieczeństwa użytkowania środków chemicznych, stosowanych podczas zabiegów intensyfikacyjnych i eksploatacyjnych w warunkach otworowych;

analizy zanieczyszczeń gleby i ścieków, odpadów wiertniczych i eksploatacyjnych.

Kierownik: dr hab. inż. Teresa Steliga, prof. INiG - PIB Adres: ul. Armii Krajowej 3, 38-400 Krosno Telefon: 1343660 29, 134368941 w. 5222 Faks: 134367971 E-mail: teresa.steliga@inig.pl

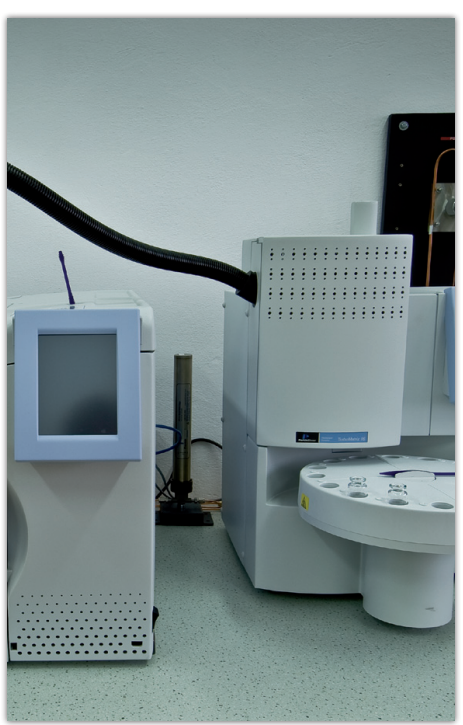

INSTYTUT NAFTY I GAZU

- Państwowy Instytut Badawczy 